\title{
Comparison of ultrasound and histopatological findings breast cancer between women aged below and above 40 years.
}

\author{
Suraini Mohamad Saini' ${ }^{1}$, Norafida Bahari², Idris Ibrahim ${ }^{3}$, Hasyma Abu Hassan ${ }^{4}$, Ezamin Abdul \\ Rahim $^{5}$, Shahad Abdul Wahhab Ibraheem ${ }^{6}$, Nuratika Baharom ${ }^{7}$, Shi Ni Lim ${ }^{8}$
}

Department of Radiology, Faculty of Medicine and Health Sciences, Universiti Putra Malaysia, 43400 Selangor, Malaysia

\begin{abstract}
Breast cancer is the most common cancer among females, but breast cancer incidence in young women is low. There are limited studies of breast cancer in this age group in Malaysia, while there are conflicting data regarding these women's prognosis compared to older patients. This study describes the common features presented by breast carcinoma on histopathological and ultrasound findings. Objective: To compare the ultrasound findings and histopathological characteristics of breast cancer for women aged below 40 years and those aged 40 years and above. Methodology: This was a retrospective, cross-sectional study using secondary data, in which the data was collected respectively from patient's clinical histories, radiology findings, and histopathology reports of patients with breast cancer in Hospital Serdang from 1 January 2009 until 31 December 2018. Patients were divided into two age groups (ages below 40, ages 40 and above). Results: 205 patients were included in this study. The most common type of breast carcinoma is invasive ductal carcinoma. Common features are grade II breast cancer cells, DCIS high grade, stage 2 (TNM), tumour size of T2 and lymph node invasion. The majority of tumours are positive with oestrogen receptor, progesterone receptor, and HER2 receptor. Conclusion: Younger age group has a similar feature with the older age group, except they have late stage and progesterone negativity. There is no significant association between age group, ultrasound, histological features, and breast carcinoma receptors.
\end{abstract}

Keywords: ultrasound breast, histopathological, breast cancer

Article Received: 18 October 2020, Revised: 3 November 2020, Accepted: 24 December 2020

\section{INTRODUCTION}

Breast cancer is the most cancer in the prevalent among female but rarely occur in young women. Women aged younger than 35 years account for less than $4 \%$ of cases diagnosed [1,2]. Although breast cancer incidence is low compared to the older age group, breast cancer in the young has gained increase attention to improve diagnosis and prognosis. Several studies have proved that women who developed breast cancer at a younger age have lower survival rates than older patients [1,2,3]. Plus, the younger women with breast cancer may have more aggressive tumours biology such as high proliferation rate, high histology grade, larger tumour size, positive lymph node, and the absence of steroid receptors [4]. Cancer or lesion findings on a mammogram will confirm by validating the lesion density, size, shape, and nature [5]. However, in ultrasound, cancer or lesions are evaluated according to margin, length, and echogenicity. Hence, this study will show the characterization of breast tumours using ultrasound and its correlation with histopathological findings, which is essential for quality control and improving the interpretation by ultrasound for young women aged below 40 years compared to those aged 40 years above.

This study aims to describe breast carcinoma's common features on ultrasound findings for women aged above and below 40 years and different racesthe association between age and ultrasound findings; between age and clinical-pathological findings from this research.

\section{II.MATERIAL AND METHODS}

\subsection{Methods -}

The study was a retrospective study using secondary data. The data were collected from patients' clinical histories, radiology findings, and histopathology reports of patients with breast cancer in Hospital Serdang from 1 January 2009 until 31 December 2018. Patients with breast carcinoma from the database were divided into two age groups (ages below 40, ages 40 and above). The estimated proportion of women below 40 who have negative oestrogen receptor $\left(\mathrm{P}_{1}\right)$ is 0.388 whereas the estimated proportion of women above and equal to 
40 who have negative oestrogen receptor $\left(\mathrm{P}_{2}\right)$ is 0.216 (Colleoni et al., 2002). The presence of hormone receptor is a prognostic factor in breast cancer.

In a standardized normal distribution curve, $\mathrm{z}$ value actually represents the area under the curve for a normal distribution graph, and often it actually also proves the confidence level in our study. We have decided to set the value of confidence level at $95 \%$ which gives the $\mathrm{Z}_{(1-\alpha / 2)}$ value of 1.96. The power of this study is set at $80 \%$ which gives the $Z_{(1-\beta)}$ value of 0.84 .

If $\mathrm{P}_{1}=0.388, \mathrm{P}_{2}=0.216$, hence $\mathrm{P}=0.302$, whereas $\mathrm{Z}$ $(1-\alpha / 2)=1.96$ and $Z_{(1-\beta)}=0.84$. So,

$\mathrm{n}=\{[1.96 * \sqrt{2}(0.302)(1-0.302)]+[0.84 * \sqrt{ }(0.388)(1-$

$0.388)+0.216(1-0.216)]\}^{2}$

$(0.388-$

$0.216)^{2}$

$$
\begin{aligned}
& n=110.54 \\
& n \approx 111 \text { samples }
\end{aligned}
$$

The $n$ calculated was multiplied by 2 groups; therefore, it was shown that the sample size for our study should be at least 222 samples.

Histological and ultrasound findings on breast carcinoma were obtained and analysed using SPSS Statistics version 22.0 for windows.

\subsection{Statistic Analysis-}

Statistical calculation was performed using the standard statistical software package, SPSS 22.0 for Windows. Cross sectional descriptive study was used to assess the histopathological features of breast $(\mathrm{N}=205)$ cancer including types of breast carcinoma, grading and staging for patients aged above and below 40 years old. Besides, cross sectional descriptive study also was used to assess the ultrasound findings of breast cancer according to the age group. Chi-square test was used to analyse an association between two categorical variables: age with ultrasound findings and age with histopathological findings. In all statistical analyses, a ' $p$ ' value of $<0.05(95 \%$ confidence interval) is considered to be statistically significant. The table for data analysis will be attached in Appendix session.

Ethical approval has been obtained from the Medical and Ethics Committee to conduct this study (NMRR16-715-30490 (IIR)

\section{RESULT}

Two hundred five patients with majority of patients $(n=164)$ are in the age group of "above and equal to 40 " which contributed to $80.0 \%$ of patients.

Out of 205 patients, majority of patients are Malay $(n=122,59.5 \%)$ followed by Indian $(n=41,20.0 \%)$, Chinese $(n=36,17.6 \%)$ and others $(n=6,2.9 \%)$. Among others, there is $4(2.0 \%)$ of the patients who are non-Malaysian.

\subsection{Distribution of Breast Cancer by} Histopathological findings and staging.

Table-1. Distribution of Breast Cancer Patients by Histopathological findings and staging with Age Group 


\begin{tabular}{|c|c|c|c|c|}
\hline & \multicolumn{2}{|c|}{ Age Group } & \multirow[t]{2}{*}{ Total (N) } & \multirow[t]{2}{*}{ Percentage (\%) } \\
\hline & $<40$ & $\geq 40$ & & \\
\hline \multicolumn{5}{|l|}{ Histological findings } \\
\hline \multicolumn{5}{|l|}{ Type of tumours } \\
\hline DCIS & $4(9.8)$ & $12(7.5)$ & 16 & 8.0 \\
\hline \multicolumn{5}{|l|}{ Invasive ductal carcinoma (IDC) } \\
\hline NOS & $8(19.5)$ & $16(10.0)$ & 24 & 11.9 \\
\hline NST & $9(22.0)$ & $38(23.8)$ & 47 & 23.4 \\
\hline Not mentioned & 18 (43.9) & $77(48.1)$ & 95 & 47.3 \\
\hline Invasive papillary carcinoma & $0(0.0)$ & $4(2.5)$ & 4 & 2.0 \\
\hline Invasive lobular carcinoma & $0(0.0)$ & $7(4.4)$ & 7 & 3.5 \\
\hline Mucinous carcinoma & $2(4.9)$ & $4(2.5)$ & 6 & 3.0 \\
\hline Inflammatory carcinoma & $0(0.0)$ & $1(0.6)$ & 1 & 0.5 \\
\hline Phyloides tumour & $0(0.0)$ & $1(0.6)$ & 1 & 0.5 \\
\hline Total & 41 & 160 & 201 & 100.0 \\
\hline \multicolumn{5}{|l|}{ Grading breast cancer cells } \\
\hline 1 (well differentiated) & $8(20.5)$ & $34(24.6)$ & 42 & 23.7 \\
\hline 2 (moderately differentiated) & $15(38.5)$ & 55 (39.9) & 70 & 39.5 \\
\hline 3 (poorly differentiated) & $12(30.8)$ & $36(26.1)$ & 48 & 27.1 \\
\hline \multicolumn{5}{|l|}{ Grading ductal carcinoma in situ (DCIS) } \\
\hline Low grade (DCIS) & $2(5.1)$ & $2(1.4)$ & 4 & 2.3 \\
\hline Intermediate grade (DCIS) & $0(0.0)$ & $5(3.6)$ & 5 & 2.8 \\
\hline High grade (DCIS) & $2(5.1)$ & $6(4.3)$ & 8 & 4.5 \\
\hline Total & 39 & 138 & 177 & 100.0 \\
\hline \multicolumn{5}{|l|}{ Stage } \\
\hline 1 & $2(5.6)$ & $13(8.8)$ & 15 & 8.2 \\
\hline 2 & $13(36.1)$ & $73(49.3)$ & 86 & 46.7 \\
\hline 3 & $17(47.2)$ & $49(33.1)$ & 66 & 35.9 \\
\hline 4 & $4(11.1)$ & $13(8.8)$ & 17 & 9.2 \\
\hline Total & 36 & 148 & 184 & 100.0 \\
\hline \multicolumn{5}{|l|}{ T-Tumour Size } \\
\hline $\mathrm{T} 1-<2 \mathrm{~cm}$ & $3(8.6)$ & $26(17.7)$ & 29 & 15.9 \\
\hline $\mathrm{T} 2->2-5 \mathrm{~cm}$ & $17(48.6)$ & 69 (46.9) & 86 & 47.3 \\
\hline $\mathrm{T} 3->5 \mathrm{~cm}$ & $11(31.4)$ & $29(19.7)$ & 40 & 22.0 \\
\hline $\begin{array}{l}\text { T4 - tumour extends to skin or chest } \\
\text { wall }\end{array}$ & $4(11.4)$ & $23(15.6)$ & 27 & 14.8 \\
\hline Total & 35 & 147 & 18 & 100.0 \\
\hline \multicolumn{5}{|l|}{$\mathrm{N}$ - Node Involvement } \\
\hline Yes & $26(74.3)$ & $86(57.0)$ & 112 & 60.2 \\
\hline No & $8(22.9)$ & $60(39.7)$ & 68 & 36.6 \\
\hline Total & 35 & 151 & 186 & 100.0 \\
\hline
\end{tabular}




M - Metastasis
Yes
No
Total

Table 1 shows that the most common type of breast carcinoma is invasive ductal carcinoma in both age groups. The common features of breast carcinoma presented by both age groups are grade 2 (moderately differentiated), DCIS high grade, tumour size of T2,
$21(14.0)$

$103(68.7)$

150
17.2

66.7

100.0

Table-2. Association between Age Group and Types of Tumour.

\begin{tabular}{|c|c|c|c|c|c|}
\hline \multirow[t]{2}{*}{ Variable } & \multicolumn{3}{|c|}{ Types of tumour } & & \multirow[t]{2}{*}{ p-value } \\
\hline & $\begin{array}{l}\text { IDC } \\
\text { n }(\%)\end{array}$ & $\begin{array}{l}\text { DCIS } \\
\mathrm{n}(\%)\end{array}$ & $\begin{array}{l}\text { Others } \\
\mathrm{n}(\%)\end{array}$ & $\begin{array}{l}\text { Total } \\
\mathrm{n}(\%)\end{array}$ & \\
\hline \multicolumn{6}{|c|}{ Age group } \\
\hline$<40$ & $35(85.4)$ & $4(9.8)$ & $2(4.9)$ & $41(100.0)$ & $0.543^{*}$ \\
\hline$\geq 40$ & $131(81.9)$ & $12(7.5)$ & 17 (10.6) & $160(100.0)$ & \\
\hline
\end{tabular}

Our study has shown that regardless of age and ethnicity, the patients' most common tumour type is the invasive ductal tumour. There is no significant association between age group and type of tumours with a p-value of 0.543 , which is more than 0.05 lymph node invasion, and do not distantly metastasize. The younger age group has a higher percentage of the later stage (stage 3) than older age groups, mostly presented at stage 2 .

Table-3. Association between Age Group and Grade (other than DCIS)

\begin{tabular}{|c|c|c|c|c|c|c|c|}
\hline \multirow[t]{2}{*}{ Variable } & \multicolumn{4}{|c|}{ Grade (other than DCIS) } & \multirow[t]{2}{*}{$x^{2}$} & & \multirow[t]{2}{*}{$p$-value } \\
\hline & I & II & III & Total & & & \\
\hline \multicolumn{8}{|l|}{ Age group } \\
\hline$<40$ & $8(22.9)$ & 15 (42.9) & $12(34.3)$ & 35 (100.0) & 0.479 & 2 & 0.783 \\
\hline$\geq 40$ & $34(27.2)$ & $55(44.0)$ & $36(28.8)$ & $125(100.0)$ & & & \\
\hline
\end{tabular}

Both age groups have shown grade 2 as their most prevalent grade, which proved no significant association between age group and grade of the tumour with the p-value of 0.783 , which is more than 0.05 (Table 3 ).

Table-4. Association between Age Group and Stage of breast cancer

\begin{tabular}{|lllllll|}
\hline Variable & \multicolumn{9}{c}{ Stage } & \multicolumn{2}{c|}{ p-value } \\
\cline { 2 - 7 } & 1 & 2 & 3 & 4 & Total & \\
Age group & $\mathrm{n}(\%)$ & $\mathrm{n}(\%)$ & $\mathrm{n}(\%)$ & $\mathrm{n}(\%)$ & $\mathrm{n}(\%)$ & \\
$<40$ & $2(5.6)$ & $13(36.1)$ & $17(47.2)$ & $4(11.1)$ & $36(100.0)$ & $0.348^{*}$ \\
$\geq 40$ & $13(8.8)$ & $73(49.3)$ & $49(33.1)$ & $13(8.8)$ & $148(100.0)$ & \\
\hline
\end{tabular}

The results showed no significant association 3.2 Distribution of Breast Cancer by Receptor between age group and stage of the tumour with a p- Status. value of 0.348 , which is more than 0.05 (Table 4 ).

Table-5. Distribution of Breast Cancer Patients by Receptor Status and Age Group $(\mathrm{N}=205)$

\begin{tabular}{|c|c|c|c|c|}
\hline \multirow[t]{2}{*}{ Receptor Status } & \multicolumn{2}{|c|}{ Age Group } & \multirow[t]{2}{*}{ Total $(\mathrm{N})$} & \multirow[t]{2}{*}{ Percentage (\%) } \\
\hline & $<40$ & $\geq 40$ & & \\
\hline
\end{tabular}




\begin{tabular}{|l|c|c|r|r|}
\hline Oestrogen receptor (ER) & $20(54.1)$ & $88(66.7)$ & 108 & 63.9 \\
$\quad$ Positive & $17(45.9)$ & $44(33.3)$ & 61 & 36.1 \\
$\quad$ Negative & 37 & 132 & 169 & 100.0 \\
Total & $18(48.6)$ & $72(55.8)$ & 90 & 54.2 \\
\hline Progesterone receptor (PR) & $19(51.4)$ & $57(44.2)$ & 76 & 45.8 \\
$\quad$ Positive & 37 & 129 & 166 & 100.0 \\
$\quad$ Negative & & & & \\
Total & $6(75.0)$ & $11(68.8)$ & 17 & 70.8 \\
& $2(25.0)$ & $5(31.3)$ & 7 & 29.2 \\
\hline HER2 receptor & 8 & 16 & 24 & 100.0 \\
$\quad$ Positive & & & & \\
$\quad$ Negative & & & \\
Total & & & \\
\hline
\end{tabular}

Table 5 shows that most tumours are positive with oestrogen receptor, progesterone receptor, and HER2 receptor. However, younger age groups are more likely to be negative with progesterone receptor.
Specific molecular subtypes such as Lumina A, Lumina B, or triple-negative is not discussed in this study due to not much data for the HER2 receptor.

Table-6. Association between Age Group and Oestrogen Receptor.

\begin{tabular}{|c|c|c|c|c|c|c|}
\hline \multirow[t]{2}{*}{ Variable } & \multicolumn{3}{|c|}{ Oestrogen Receptor } & \multirow[t]{2}{*}{$x^{2}$} & \multirow[t]{2}{*}{ Df } & \multirow[t]{2}{*}{ p-value } \\
\hline & $\begin{array}{l}\text { Positive } \\
\mathrm{n}(\%)\end{array}$ & $\begin{array}{l}\text { Negative } \\
\mathrm{n}(\%)\end{array}$ & $\begin{array}{l}\text { Total } \\
\mathrm{n}(\%)\end{array}$ & & & \\
\hline \multicolumn{7}{|l|}{ Age group } \\
\hline$<40$ & $20(54.1)$ & $17(45.9)$ & $37(100.0)$ & 1.993 & 1 & 0.178 \\
\hline$\geq 40$ & $88(66.7)$ & $44(33.3)$ & $132(100.0)$ & & & \\
\hline
\end{tabular}

The results from table 6 showed that there were no significant association between age group and oestrogen receptor $(\mathrm{p}=0.178)$.

Table-7. Association between Age Group and Progesterone Receptor.

\begin{tabular}{|c|c|c|c|c|c|c|}
\hline \multirow[t]{2}{*}{ Variable } & \multicolumn{3}{|c|}{ Progesterone Receptor } & \multirow[t]{2}{*}{$x^{2}$} & \multirow[t]{2}{*}{ Df } & \multirow[t]{2}{*}{ p-value } \\
\hline & $\begin{array}{l}\text { Positive } \\
\mathrm{n}(\%)\end{array}$ & $\begin{array}{l}\text { Negative } \\
\mathrm{n}(\%)\end{array}$ & $\begin{array}{l}\text { Total } \\
\mathrm{n}(\%)\end{array}$ & & & \\
\hline \multicolumn{7}{|l|}{ Age group } \\
\hline$<40$ & $18(48.6)$ & $19(51.4)$ & $37(100.0)$ & 0.595 & 1 & 0.460 \\
\hline$\geq 40$ & $72(55.8)$ & $57(44.2)$ & $129(100.0)$ & & & \\
\hline
\end{tabular}

The results from table 7 showed that there were no significant association between age group and progesterone receptor $(\mathrm{p}=0.460)$.

Table-8. Association between Age Group and HER2 Status.

\begin{tabular}{|c|c|c|c|c|c|c|}
\hline \multirow[t]{2}{*}{ Variable } & \multicolumn{3}{|c|}{ HER2 status } & \multirow[t]{2}{*}{$x^{2}$} & \multirow[t]{2}{*}{ Df } & \multirow[t]{2}{*}{ p-value } \\
\hline & $\begin{array}{l}\text { Positive } \\
\mathrm{n}(\%)\end{array}$ & $\begin{array}{l}\text { Negative } \\
\mathrm{n}(\%)\end{array}$ & $\begin{array}{l}\text { Total } \\
\mathrm{n}(\%)\end{array}$ & & & \\
\hline \multicolumn{7}{|l|}{ Age group } \\
\hline$<40$ & $6(75.0)$ & $2(25.0)$ & $8(100.0)$ & & & $1.000 *$ \\
\hline$\geq 40$ & $11(68.8)$ & $5(31.3)$ & $16(100.0)$ & & & \\
\hline
\end{tabular}

*: Fisher's exact value

The results showed that there were no significant association between age group and HER2 status $(\mathrm{p}=1.000)$.

\subsection{Distribution of Breast Cancer by Ultrasound findings.}


Table-9. Distribution of Breast Cancer Patients by Ultrasound Findings and Age Group (N=205)

\begin{tabular}{|c|c|c|c|c|}
\hline \multirow[t]{2}{*}{ Ultrasound Findings } & \multicolumn{2}{|c|}{ Age Group } & \multirow[t]{2}{*}{ Total (N) } & \multirow[t]{2}{*}{ Percentage (\%) } \\
\hline & $<40$ & $\geq 40$ & & \\
\hline \multicolumn{5}{|l|}{ Quadrant } \\
\hline Upper Outer & $30(73.2)$ & $68(42.2)$ & 98 & 48.5 \\
\hline Upper Inner & $7(17.1)$ & $38(23.6)$ & 45 & 22.3 \\
\hline Lower Outer & $2(4.9)$ & $22(13.7)$ & 24 & 11.9 \\
\hline Lower Inner & $0(0.0)$ & $21(13.0)$ & 21 & 10.4 \\
\hline Retroareolar & 2 (4.9) & $12(7.5)$ & 14 & 6.9 \\
\hline Total & 41 & 161 & 202 & 100.0 \\
\hline \multicolumn{5}{|l|}{ Length } \\
\hline $0-0.99$ & $5(12.5)$ & $23(15.1)$ & 28 & 14.6 \\
\hline $1-1.99$ & $9(22.5)$ & $39(25.7)$ & 48 & 25.0 \\
\hline $2-2.99$ & $11(27.5)$ & $29(19.1)$ & 40 & 20.8 \\
\hline $3-3.99$ & $9(22.5)$ & $31(20.4)$ & 40 & 20.8 \\
\hline $4-4.99$ & $4(10.0)$ & $14(9.2)$ & 18 & 9.4 \\
\hline $5-5.99$ & $1(2.5)$ & $7(4.6)$ & 8 & 4.2 \\
\hline $6-6.99$ & $0(0.0)$ & $1(0.7)$ & 1 & 0.5 \\
\hline $7-7.99$ & $0(0.0)$ & $1(0.7)$ & 1 & 0.5 \\
\hline 8-8.99 & $1(2.5)$ & $4(2.6)$ & 5 & 2.6 \\
\hline $10-10.99$ & $0(0.0)$ & $1(0.7)$ & 1 & 0.5 \\
\hline $11-11.99$ & $0(0.0)$ & $1(0.7)$ & 1 & 0.5 \\
\hline $14-14.99$ & $0(0.0)$ & $1(0.7)$ & 1 & 0.5 \\
\hline Total & 40 & 152 & 192 & 100.0 \\
\hline \multicolumn{5}{|l|}{ Margin } \\
\hline Irregular & 32 (91.4) & $130(87.2)$ & 162 & 88.0 \\
\hline Well-defined & $3(8.6)$ & $19(12.8)$ & 22 & 12.0 \\
\hline Total & 35 & 149 & 184 & 100.0 \\
\hline \multicolumn{5}{|l|}{ Echotexture } \\
\hline Hypoechoic & 34 (97.1) & $136(94.4)$ & 170 & 95.0 \\
\hline Hyperechoic & $0(0.0)$ & $8(5.6)$ & 8 & 4.5 \\
\hline Others & $1(2.9)$ & $0(0.0)$ & 1 & 0.6 \\
\hline Total & 35 & 144 & 179 & 100.0 \\
\hline \multicolumn{5}{|l|}{ Ultrasound lexicon BI-RADS } \\
\hline 3 & $0(0.0)$ & $5(3.2)$ & 5 & 2.6 \\
\hline 4 & $13(36.1)$ & $51(32.3)$ & 64 & 33.0 \\
\hline 5 & $19(52.8)$ & $91(57.6)$ & 110 & 56.7 \\
\hline 6 & $4(11.1)$ & $11(7.0)$ & 15 & 7.7 \\
\hline Total & 36 & 158 & 194 & 100.0 \\
\hline
\end{tabular}

Table 9 shows that the common ultrasound findings of breast carcinoma presented by both age groups are upper outer quadrant, size less than $5 \mathrm{~cm}$, irregular margin, hypoechoic, and ultrasound lexicon BIRADS 5.

Table-10. Association between Age Group and Quadrant of Tumour. 


\begin{tabular}{|c|c|c|c|c|c|c|c|}
\hline \multirow{2}{*}{ Variable } & \multicolumn{3}{|c|}{ Quadrant } & & \multirow[t]{2}{*}{$x^{2}$} & \multirow[t]{2}{*}{ Df } & \multirow[t]{2}{*}{$\mathrm{p}$-value } \\
\hline & $\begin{array}{l}\text { Upper } \\
\mathrm{n}(\%)\end{array}$ & $\begin{array}{l}\text { Lower } \\
\mathrm{n}(\%)\end{array}$ & $\begin{array}{c}\text { Retroareolar } \\
\mathrm{n}(\%)\end{array}$ & $\begin{array}{l}\text { Total } \\
\mathrm{n}(\%)\end{array}$ & & & \\
\hline \multicolumn{8}{|l|}{ Age group } \\
\hline$<40$ & $37(90.2)$ & $2(4.9)$ & $2(4.9)$ & $41(100.0)$ & 10.053 & 2 & 0.006 \\
\hline$\geq 40$ & $106(65.8)$ & $43(26.7)$ & $12(7.5)$ & $161(100)$ & & & \\
\hline
\end{tabular}

Since both age groups have the upper outer quadrant within the age group, there was no significant difference. There is a significant association between age group and quadrant with the p-value of 0.006 , which is less than 0.05 (Table 10). Our study has shown that regardless of age and ethnicity, the patients' most common tumour length

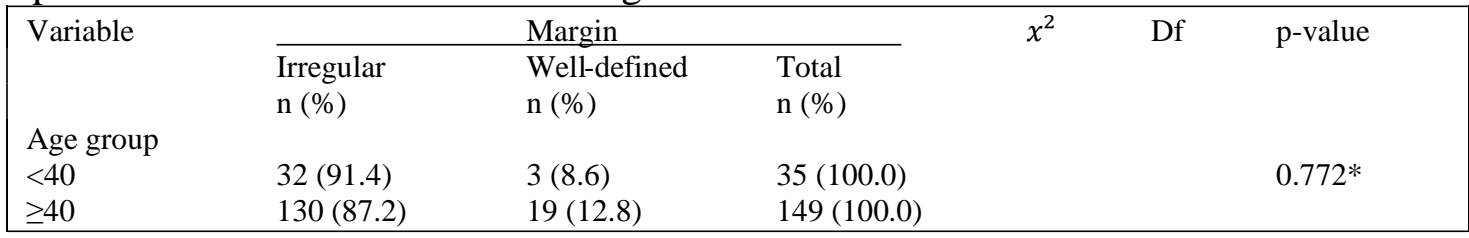

Since both age groups have irregular margins within the age group, there was no significant difference. There is no significant association between age group and margin with the p-value of 0.772 , which is more than 0.05 (Table 11). Both age groups have shown hypoechoic mass as their most prevalent echotexture is less than $5 \mathrm{~cm}$-no significant difference between younger and older age groups.

Table-11. Association between Age Group and Margin of Tumour.

\begin{tabular}{|llllll|}
\hline Variable & \multicolumn{3}{c}{ Echotexture } & p-value \\
\cline { 2 - 4 } & $\begin{array}{l}\text { Hypoechoic } \\
\mathrm{n}(\%)\end{array}$ & $\begin{array}{l}\text { Hyperechoic } \\
\mathrm{n}(\%)\end{array}$ & $\begin{array}{l}\text { Others } \\
\mathrm{n}(\%)\end{array}$ & $\begin{array}{l}\text { Total } \\
\mathrm{n}(\%)\end{array}$ & \\
$\begin{array}{l}\text { Age group } \\
<40\end{array}$ & $34(97.1)$ & $0(0.0)$ & $1(2.9)$ & $35(100.0)$ & $0.109 *$ \\
$\geq 40$ & $136(94.4)$ & $8(5.6)$ & $0(0.0)$ & $144(100.0)$ & \\
\hline
\end{tabular}

Both age groups have shown hypoechoic mass as their most prevalent echotexture of mass, which proved that there was no significant association between age group and grade of the tumour with the p-value of 0.109, which is more than 0.05 (Table 12). There is no significant association between age group and BIRADS category with the p-value of 0.650 , which is more than 0.05 .

\section{DISCUSSION}

Ultrasound is quick, widely available, well-tolerated, very safe, and relatively cheap. Ultrasound can differentiate benign and malignant breast lesions and detect occult breast cancers in dense breasts from a mammogram study [6]. Ultrasound can be a good first row image modality in breast imaging [7]. of mass, which proved that there was no significant association between age group and grade of the tumour with the p-value of 0.109 , which is more than 0.05 .

Table-12. Association between Age Group and Echotexture of Tumour
Shahad et al. showed significant associations between breast density and age group, and there was no significant association with ethnic groups [8]. Invasive ductal carcinoma is also observed as the primary histological type of breast cancer in a study conducted at Singapore-Malaysia hospital setting [9] and in a study conducted at the University Malaya Medical Centre [10]. Our study has shown that regardless of age and ethnicity, the patients' most common tumour type is the invasive ductal tumour. However, it is not significantly different between the younger and older. Age has no impact on the type of tumour, a finding similar to a study conducted in Singapore [10].

A study showed that grade 2 is the most common grade among the 4058 patients [9], which is consistent with our study. This finding is also 
supported by the study conducted at University Malaya Medical Centre [10]. Our study showed that for non-DCIS, most tumours are presented with grade II regardless of age and ethnicity, although for other ethnic groups having grade III.

Age has no impact on tumour histologic grade, a finding similar to a study conducted in Singapore [11]. Most DCIS are presented in high grade. We found other studies have shown most lesions were of high nuclear grade [12].

In this study, stage 2 has the highest percentage of patients. It is consistent with the study's finding that most Asian countries showed stage 2 at the initial presentation [13]. It is also supported by the study conducted in Universiti Kebangsaan Malaysia Medical Centre, which showed majority are presented at stage 2 [14]. However, the younger age group and Chinese have a higher percentage in presenting advanced stage at stage 3 . We found that the younger group was more likely to be diagnosed with the later-stage disease than the older group [15]. This study has similar to our findings.

There are three components for staging; they are tumour size $(\mathrm{T})$, lymph node involvement $(\mathrm{N})$, and metastasis (M). Our study has shown that T2 is the most common tumour size regardless of age and ethnicity, a similar finding in another study conducted at Tertiary Hospital, South India, which showed a majority of the tumours were T2 $(83.8 \%$ in the range of $2-5 \mathrm{~cm}$ ) [16]. Besides, most tumours showed lymph node invasion and did not distant metastasis. Only other ethnic groups showed no involvement of lymph nodes. For comparison of two age groups, it is shown that there were no differences between the two groups for pathological tumour size $(\mathrm{T})$, frequency of positive lymph nodes $(\mathrm{N})$, and distant metastasis at diagnosis (M). This finding is supported by S. Aksoy et al. (2009) study [17].

ER, PR, and HER-2 expression has prognostic and therapeutic value in breast cancer. ER and PR demonstrated a significant correlation with echo pattern and a hypoechoic or complex echo pattern was seen more often in cancers with ER or PR negativity. Cancers with ER or PR positivity respond to hormonal therapy and have a relatively good prognosis [6]. Like our case, the majority of tumours are positive with oestrogen receptor, progesterone receptor, and HER2 receptor. However, younger age groups are more likely to be negative with progesterone receptors.

Our study has shown that the most common quadrant of the tumour is the upper outer quadrant within different age groups. The study also found most lesions were at the upper outer quadrant [19] and similar to other Southeast Scotland studies [20]. Age has no impact on the tumour's quadrant, a finding similar to a study conducted in Tottori University Faculty of Medicines, Japan [21].

The length of less than $5 \mathrm{~cm}$ is also observed as the most common length of breast cancer in a study conducted at Dong-A University Hospital and University of North Carolina at Chapel Hill, USA [22]. However, the study was only conducted for 30 years old and younger women. The study also shows that the patients' most common tumour length is less than $5 \mathrm{~cm}$. We cannot find any similar articles that study the association between women in the older age group with tumour length.

An irregular shape and hypoechoic or complex echo pattern are the typical malignant features of solid breast masses (6). Our study has shown that the majority of tumours presented by the patients who have records are irregular margin and hypoechoic regardless of age. A higher percentage of irregular margin is also observed in another study [22]. This finding is also supported by the study at Dong-A University Hospital and the University of North Carolina at Chapel Hill, USA [22]. Age has no impact margin, a finding similar to a study conducted in Japan [21].

In a study conducted by Paul R Fisher et al. (2011) [23] and also in a study conducted at Dong-A University Hospital and the University of North Carolina at Chapel Hill, USA, [21] it showed that hypoechoic is the most common echogenicity of 
mass, and this is consistent with our study. Age has no impact on tumour echogenicity, a finding similar to a study conducted in Tottori University Faculty of Medicines, Japan [21].

Most of the tumours which are tested are ultrasound lexicon BIRADS 5 regardless of age. It is supported by a study that showed that BIRADS category 5 is the most typical example for the BIRADS Category, which contributed to $60 \%$ of breast malignancy [24]. Age has no impact on the BIRADS category, a finding similar to a study conducted in Japan [21].

\section{CONCLUSION}

The younger and older age group have the similar feature of breast carcinoma, except for the younger age group has a higher percentage of late stage and progesterone negativity. It will affect patients' management, and survival rate as the younger age group is the most productive time for pregnant women and women's empowerment to family and country. Therefore, younger age women should be encouraged to do ultrasound breast screening.

There is no significant association between age groups and histological features and breast carcinoma receptors. There is no significant difference in common ultrasound findings for both age groups. The recommendation is to extend the research to the other hospital, which is well known as a referral centre for breast cancer, such as Hospital Putrajaya, and increase the study's younger age group.

\section{REFERENCES}

1) Chung M., Chang H., Bland K., Wanebo H. "Younger women with breast carcinoma have a poorer prognosis than older women". Cancer, 77(1): 97-103, 1996. DOI: https://doi.org/10.1002/(SICI)10970142(19960101)77:1<97::AID-

CNCR16>3.0.CO;2-3

2) Colleoni M., Rotmensz N., Robertson C., Orlando L., Viale G., Renne G et al. "Very young women ( $<35$ years) with operable breast cancer: features of disease at presentation". Annals of Oncology, 13(2):273279, 2002.

DOI:https://doi.org/10.1093/annonc/mdf039

3) Walker R., Lees E., Webb M., Dearing, S. "Breast carcinomas occurring in young women (< 35 years) are different". $\mathrm{Br} J$ Cancer, 74(11): 1796-1800, 1996. DOI 10.1038/bjc.1996.632

4) Yao S., Xu B., Ma F., Liao Y., Fan Y. "Breast cancer in women younger than 25: clinicopathological features and prognostic factors". Annals of Oncology, 20(2): 387-389, 2008. DOI: $10.1093 /$ annonc/mdn711

5) Anis R.Z., Tay Q.I., Izyan R.M., Rozi M., Suzana A.H., Suraini M.S., Mostafa L. "Relation of Breast Density with Age and Ethnicity in Malaysia". Iranian Journal of Medical Informatics, 2 (1): 1-4, 2013.

6) Sung H.K., Bo K.S, Juneyoung L., Seok J.K., Kyu R.C., Ki Y.L., Bo-Kyung J., Hee Y.K., Young-Sik Kim \& Ju-Han Lee. Correlation of ultrasound findings with histology, tumor grade, and biological markers in breast cancer". Acta Oncologica, 47:8, 1531-1538, 2008. DOI: $10.1080 / 02841860801971413$

7) Shahad A.I., Rozi M., Suraini M.S., Norafida B., Mousa A. "The normal types of ultrasound breast morphology (Glandular tissue and fat lobules) among women of different age groups In Golden Horses Health". OMICS Journal of Radiology. 5:243, 1-5, 2016. DOI: 10.4172/2167-7964.1000243

8) Shahad A.I., Rozi M., Suraini M.S., Norafida B., Mousa A. "Effect of Socio-Demographic Factors, Family Information and Gynecology History on Ultrasound Breast Morphologyin Different Age Groups". Global Journal of Medical Research, [S.1.], apr. 2017. ISSN 2249-4618. Available at:

$<$ https://medicalresearchjournal.org/index.ph p/GJMR/article/view/1408>.

Date accessed: 27 jan. 2021.

9) Bhoo P.N., Yip C., Taib N., Hartman M., Saxena N., Iau P. et al. "Breast cancer in a multi-ethnic Asian setting: Results from the Singapore-Malaysia hospital-based breast cancer registry". The Breast, 20: S75-S80, 
2011. DOI: 10.1016/j.breast.2011.01.015

10) Tan G., Choo W., Taib N., Yip C. "Factors Associated with HER2 Overexpression in Breast Cancer: Experience in an Asian Developing Country". Asian Pacific Journal of Cancer Prevention, 10: 837-840, 2009. PMID: 20104975

11) Tan E., Wong H., Ang B., Chan M. "Locally Advanced and Metastatic Breast Cancer in a Tertiary Hospital". Annals Academy of Medicine Singapore, 34(10):595-601, 2005. PMID: 16382243

12) Bellamy C., McDonald C., Salter D., Chetty U., Anderson T. "Noninvasive ductal carcinoma of the breast: The relevance of histologic categorization". Human Pathology, 24(1):16-23, $1993 . \quad$ DOI: https://doi.org/10.1016/0046-8177(93)90057$\mathrm{N}$

13) Leong S., Shen Z., Liu T., Agarwal G., Tajima T., Paik N. et al. "Is Breast Cancer the Same Disease in Asian and Western Countries". World J Surg, 34(10): 2308-2324, 2010. DOI: $10.1007 / \mathrm{s} 00268-010-0683-1$.

14) Sharifah N., Lee B., Clarence-Ko C., Tan G., Shiran M., Naqiyah I et al. "C-erbB-2 OncoProtein Expression in Breast Cancer: Relationship to Tumour Characterisitcs and Short-Term Survival in Universiti Kebangsaan Malaysia Medical Centre". Asian Pacific Journal of Cancer Prevention, 9(4):663-70. 2008. PMID: 19271345

15) Maggard M., O'Connell J., Lane K., Liu J., Etzioni D., Ko C. "Do young breast cancer patients have worse outcomes?" Journal of Surgical Research, 113(1): 109-113, 2003. DOI: 10.1016/s0022-4804(03)00179-3

16) Ambroise M., Ghosh M., Mallikarjuna V., Kurian A. "Immunohistochemical Profile of Breast Cancer Patients at a Tertiary Care Hospital in South India". Asian Pacific Journal of Cancer Prevention,12:625-629, 2011. PMID: 21627355

17) Aksoy S., Bulut N., Dizdar O., Tosur M., Meral A., Altundag K. "Pathological characteristics of very young ( $<=30$ years) breast cancer patients: a single-institution experience from Turkey". Annals of Oncology, 20(4):790-790, 2009. DOI: 10.1093/annonc/mdn794

18) Sidoni A., Cavaliere A., Bellezza G., Scheibel M., Bucciarelli E. "Breast cancer in young women: clinicopathological features and biological specificity". The Breast, 12(4): 247-250, 2003. DOI: 10.1016/s09609776(03)00095-x

19) Blichert-Toft M. "Common breast lesions. A photographic guide to diagnosis and treatment S Pilnik. Cambridge, UK: Cambridge University Press 2003". British Journal of Surgery, 19(11):250, 2004. DOI: https://doi.org/10.1002/bjs.4713

20) Aljarrah A., Miller W.R. "Trends in the distribution of breast cancer over time in the southeast of Scotland and review of the literature". Ecancermedicalscience, 8(427), 2014.

DOI: https://doi.org/10.3332/ecancer.2014.427

21) Naoko S., Yuiko H, Naoyuki U, Akira K, Yuki K, Haruki N et al. "Correlation between Ultrasound Findings of Tumor Margin and Clinicopathological Findings in Patients with Invasive Ductal Carcinoma of the Breast". Yonago Acta Medica, 59:163-168, 2016. DOI: 10.1166/jmihi.2013.1157

22) Lee, J.H., Kuzmiak, C.M., Cho, E., Park, Y.M. "Characteristic Features of Breast Cancer in Women Aged $\leq 30$ Years". Hong Kong $J$ Radiol, 22:114-22, 2019. DOI: https://doi.org/10.12809/hkjr1916879

23) Paul R.F., Ben Y.Y., Joseph P.D. Ajay M. Sherl L.M et al. "Breast cancer ultrasonography". Medscape. Update: Jan14, 2021.

24) American Scientific Publishers. "Ultrasound Diagnosis of Breast Cancer". Journal of Medical Imaging and Health Informatics, 3:114, 2013. DOI: 10.1166/jmihi.2013.1157 